Doi: https://doi.org/10.31578/jebs.v6i1.217

\title{
The Impact of Out-of-Class Language Activities on English as a Foreign Language Proficiency of Private University Students - (A Case of Erbil)
}

Emine Bala*

\begin{abstract}
The present study aims at revealing the impact of engagement in out-of-class learning on foreign language students' language proficiency. Accordingly, the relationship of private university EFL students' involvement in English language activities outside the classroom with their language proficiency is investigated. The researcher designed a study based on descriptive quantitative research method utilizing a questionnaire comprising 25 items and administered it to the freshmen from English language teaching, biology education, physics education, and mathematics education departments at the education faculty of a private university in Erbil. 87 participants responded to the questionnaire. The statistical analysis of data was performed through SPSS 25 data editor. The results show that the most frequent activities in which English is practiced are entertaining activities like watching movies, videos, and surfing on the Internet, and that the level of the students' involvement in English language activities outside the classroom is positively associated with their language proficiency. This research could be beneficial for language teachers to show how to encourage their students to start practice outside the classroom, for students to offer some ways to augment their language proficiency with the application of English in authentic environments, and for educational administrators to give some ideas for curriculum design including out-of-class learning.
\end{abstract}

Keywords: English as a foreign language (EFL), English language activities outside the classroom, language proficiency, out-ofclass learning, second language acquisition (SLA)

\section{Introduction}

As either the student-centered education or technology-oriented system has taken power in foreign language teaching, the necessity of the students' ability to take responsibility for their learning has increased correspondingly. Similarly, Hsieh and Hsieh (2019) advocate that the function of students in language teaching has been changed, and their ability to control the learning process has gained popularity since the focal point of the language teaching system changed from teacher-centered to studentcentered. Language learners can obtain the required for language acquisition skills as an essential benefit of the student-centered method along with constructing continuing education as the main purpose (ibid). In this respect, in-class English engagement is not considered enough for acquiring the language properly, and most of researchers have emphasized the significance of involvement in practicing English outside the classroom independently (Benson, 2013; Benson \& Reinders, 2011; Grau, 2009; Nunan, 2012; Ranta, 2010; Sundqvist, 2009; Sundqvist \& Sylvén, 2016; Olsson, 2016).

According to Nunan (2012), the ones who can use the opportunities to apply their language skills are defined as competent learners. Furthermore, he creates out-of-class activities for his students to engage them in their learning at least three

${ }^{*}$ Tishik International University, Iraq/KRG 
hours a week consistently to either boost the language application or encourage them to manage the out-of-school learning process.

In literature, some researchers used a specific term Extramural English (EE) for out-of-classroom activities. It was first introduced by Sundqvist (2009) comprising the characteristics of input as well as the output of the language. It represents any kind of English language engagement outside the classroom either intentionally or unconsciously boosting the students' language skills and autonomy level. On the other hand, Benson and Reinders (2011) present the term out-of-class and out-of-school learning representing the practices applied by the students outside the school to enhance their subjects' knowledge (p.9). Therefore, the terms can be used interchangeably.

\subsection{Research Problem, Objectives and Questions}

Benson (2013) states that numerous teachers agree on the idea that if learners incorporate in-class knowledge into out-of-class practices, they make more progress in in-class learning as well. The number of studies dealing with out-of-class language learning has been increasing due to the ascending attention to autonomous learning (Benson \& Reiders, 2011). Within this context, the researcher discussed a private university language instructors' ideas about EFL students' manners towards out-of-class English practice. They claimed that students' language application level outside the classroom was not at desirable level, so teachers were struggling to boost students' in-class learning. Based on the instructors' observations on students' insufficient language production, the researcher decided to examine the impact of out-of-class English language practice on EFL students' language proficiency at a private university's education faculty considering it as one of the fundamental issues in language learning by either practitioners or students. Based on this problem, the following research objectives and questions were formulated.

The present study aims at:

1. revealing the amount of students' English practice out of classroom,

2. diagnosing the relationship between out-of-class English study and language proficiency level, besides, it aims at identifying the learners who need to be encouraged to employ the target language in authentic environments.

3. Accordingly, two research questions emerged to be investigated based on the objectives:

4. To what extent do the students engage in out-of-class English activities?

5. To what extent are out-of-class activities related to the students' language proficiency?

\section{Literature Review}

Benson (2013) mentions the concept of out-of-class learning, which is described as any actions related to learning outside the classroom including self-learning, naturalistic language acquisition, or self-governing naturalistic language acquisition. Sundqvist (2009) also highlights out-of-class activities, using the term of Extramural English (EE) in his doctoral dissertation. The word itself originated from Latin extra, which stands for outside, and mural infers to the wall. So extramural English is interpreted in the manner of English outside the walls (p.40). Accordingly, EE indicates the English in which students are included or meet out of the classroom during their free time (not as part of compulsory homework). However, Sundqvist claims that though Benson's depiction of self-governing naturalistic language acquisition corresponds to $E E$, they differ in a significant point. Namely, the learners should not always have a conscious purpose to learn English outside the classroom, rather they can find themselves in L2 acquisition naturally. 
However, in the present study, out-of-class learning, or activities are used as any activities related to English in real settings in which the students engage either for the intention of learning or just for fun. The term is used as learning not dealing with homework assignment, but students' independent choice to develop their language skills. Besides out-ofclass learning, language proficiency is another concept of this research which is described by Long and Richards (1990) as the sociolinguistic, grammatical and discourse competence in a foreign /second language. In the present study, it refers to the ability to use the foreign language orally and in writing fluently and adequatley. Lai, Zhu, and Gong (2015), as well as Richards (2015) and Sundqvist (2011) assert that language proficiency is completely related to the learning outside the classroom, and Benson, Chik and Lim (2003) and Borrero and Yeh (2010) (as cited in Lai, Zhu \& Gong, 2015) state that proficient language students normally use all opportunities for out-of-class learning.

According to the findings of several studies, Swedish ninth graders' vocabulary and oral proficiency level is positively affected by out-of-class activities such as reading books, reading newspapers/magazines, watching TV, watching films, surfing the Internet, playing video games, listening to music (Sundqvist, 2009, p.7). English outside the classroom through multimedia is also an essential topic among Bangladeshi private universities' EFL students (Ferdous, 2013). In the Finnish case, Ranta (2010) highlights the significance of out-of-class English in authentic environments based on the research among upper secondary school students' and English teachers' attitudes. Grau (2009) discovered the activities outside the classroom in which German students engage in their free time and the obtained data shows that out-of-class English is not incorporated in the language classroom. Furthermore, Sargsyan and Kurghinyan (2016) state that Armenian EFL students employ English outside the classroom mostly via social media, listening to music, watching films, traveling, and surfing on the Internet, respectively.

Besides, Erk et al. (2003 as cited in Waite, 2011) advocate that pleasure and independence in learning promote a better learning and language use. Therefore, learners will remember those words quicker which they learnt in positive settings rather than the ones learnt in a negative (stressful) atmosphere, because, while they are employing English out of class, on their own initiative and not as an assessed task, they have fun and feel independent to make their own choices.

A qualitative study conducted in Turkey by Coskun (2016), which lasted for six weeks, supported the idea expressed by Erk et al. (2003). Coskun examined the advantages of oral activities fulfilled outside the classroom according to public university EFL freshmen students' opinions and found that the speaking activities selected by them independently positively affected their vocabulary, pronunciation and fluency along with higher-order thinking skills and self-esteem.

Chan (2016) conducted an in-depth qualitative research including six competent secondary school learners engaging in out-of-school activities and found that the in-class performance and out-of- class activities influence each other positively. Bialystok (1981), who first emphasized the significance of language practice in authentic environments beyond the school walls, underlined the phenomenon of functional language which incorporates into commination activities. Also, she expressed the opinion that authentic situations provoke the most effective functional practice occurring out-of-class. Additionally, Bialystok's functional practice is compared to extramural English exposure in Lancaster's (2018) research.

Borrero and Yeh (2010, as cited in as cited in Lai, Zhu \& Gong, 2015), Lai and Gu (2011), Nunan and Richards (2015), Sylvén (2006), as well as Piirainen-Marsh and Tainio (2009) state that proficient language learners are regularly involved in activities outside the classroom in natural settings. In addition, Victori and Lockhart (1995) and Wenden (2001) claim that the exposure to EE activities enhances the cognition of foreign language learning and encourages the students to proceed learning.

De Wilde, Brysbaert and Eyckmans (2020) conducted a survey with 780 Dutch-speaking children aged 10 to 12 concerning language learning activities in order to investigate the degree of EFL primary school students' language engagement outside the 
classroom and factors affecting involvement in informal learning. According to the results, gaming, social media and chatting were found the most useful forms of input identified as interactive activities.

Maros and Saad (2016) studied a Malaysian out-of-class English case. They discovered that international master and doctorate students practice English mostly through watching movies and television programmes, and technological tools such as Internet, online dictionaries, spelling or grammar checkers. Additionally, language learning strategies training could be utilized to promote students' ability to create their learning setting outside the classroom and to become lifelong learners (Bala \& Bala, 2018). These trainings contribute to the increase of language proficiency.

On the other hand, there are some hindering factors that discourage students to use English in real settings. Shvidko, Evans and Hartshorn (2015) conducted a study revealing ESL students' perspectives about hampering factors affecting L2 use outside of the classroom in USA. They found out a variety of sociocultural (group/peer pressure, fear to making mistakes, etc.), linguistic (poor language ability, habit for translating L2 into L1, etc.), individual (personality types and motivation), and psychological (affective factors) reasons that prevent learners from applying L2 out-of-class.

Overall, the application of foreign language in authentic environments promotes the learners' linguistic and communicative skills (Tavakoli, Shakeri \& Granbarzadeh, 2016). Richards (2015) defines in-class learning and out-of-class practice as two significant elements of second language learning. He asserts that what is done as teaching inside the classroom is to help the students use the language in real settings.

\section{Research Methods}

\subsection{Research Methodology}

The present study has been designed based on a quantitative methodology, as its aim was to gather numerical data (Williams, 2007). It utilizes a questionnaire survey in order to reveal the average level of students' English use in authentic environment. The research was non-experimental (descriptive), as its objective was to define both the EFL freshmen's out-of-class language practice activities and the extent to which out-of-class English activities are related to the EFL students' language proficiency accordingly.

\subsection{Research design}

\subsubsection{Instrumentation}

The researcher developed a 25 -item questionnaire (see the appendix) with 5 -point Likert scale ( $1=$ Never, 2 =Seldom, $3=$ Sometimes, 4=Often, $5=$ =Almost always) adapted from Spratt, Humphreys and Chan (2002), which ensured the validity and the reliability of the instrument. However, as it was adapted, to ensure the content validity, it was assessed by three experts in the field. It was also piloted with ten students who did not take part in the survey. In the process of piloting the students answered the questionnaire twice, with a little break. As the correlation of the answers turned out 0.85 , it meant that the students understood the items well. The questionnaire included participants' demographic data and items revealing which kinds of English activities the students engaged in out of class. As the participants were only first year EFL students, the questionnaire was translated into their native language by a language expert checking by three first language experts to ensure the relevance of translation and comprehensibility. 


\subsubsection{Setting}

At the beginning of the fall term, a language proficiency test was administered to all first-year students at the faulty of education to identify their language proficiency level. According to their results, they were allocated to groups corresponding to their proficiency level.

\subsubsection{Participants}

The study was carried out at education faculty of a private university in Erbil (Iraq). Convenience sampling method was employed for the participant selection to save the time and collect the data in a short time. Hence, the sample of this research participants comprised of 87 freshmen in English language teaching (ELT), biology education, physics education and mathematics education departments. The first-year students were selected purposefully, as this was their foundation year in which intensive English courses in four skills were provided.

The gender distribution of the participants was $65.5 \%$ female $(n=57)$ and $34.5 \%$ male $(n=30)$ students. The research sample comprised of 19 students from English language teaching, 18 from physics, 25 from biology, and 25 mathematics education departments. The age range of the participants was 18 to 22. Most of the students were in level A2 (n=51), and level A1 ( $n=20)$, level B1 $(n=16)$ respectively according to Common European Framework. $96.6 \%$ of the students' $(n=84)$ native language is Kurdish whereas $1.1 \%(n=1)$ is Arabic and $2.3 \%(n=2)$ is other (see Appendix for tables).

\section{Participants' data}

Table 1. The number of the participants according to the departments

\begin{tabular}{llllll}
\hline Department & & & & & \\
\hline & & Frequency & Percent & Valid Percent & $\begin{array}{l}\text { Cumulative } \\
\text { Percent }\end{array}$ \\
Valid & English & 19 & 21.3 & 21.8 & 21.8 \\
& Physics & 18 & 20.2 & 20.7 & 42.5 \\
& Mathematics & 25 & 28.1 & 28.7 & 71.3 \\
& Biology & 25 & 28.1 & 28.7 & 100.0 \\
& Total & 87 & 97.8 & 100.0 & \\
Missing & System & 2 & 2.2 & & \\
\hline
\end{tabular}

Table 2. The age of the participants

\begin{tabular}{llllll}
\hline \multicolumn{5}{c}{ Age } \\
& & Frequency & Percent & Valid Percent & $\begin{array}{l}\text { Cumulative } \\
\text { Percent }\end{array}$ \\
\hline \multirow{4}{*}{ Valid } & 18 & 27 & 30.3 & 31.0 & 31.0 \\
& 19 & 27 & 30.3 & 31.0 & 62.1 \\
& 20 & 24 & 27.0 & 27.6 & 89.7
\end{tabular}




\begin{tabular}{llllll} 
& 21 & 5 & 5.6 & 5.7 & 95.4 \\
& 22 & 4 & 4.5 & 4.6 & 100.0 \\
& Total & 87 & 97.8 & 100.0 & \\
Missing & System & 2 & 2.2 & & \\
Total & & 89 & 100.0 & & \\
\hline
\end{tabular}

\subsection{Procedure}

The researcher delivered the questionnaire to the education faculty lecturers after the permission of the dean and head of departments in order to distribute it to the first-year students during their course time, and the students in the classrooms were asked to answer the questionnaire correspondingly. On the same day, the researcher collected the papers from the lecturers.

\subsection{Research Ethics}

The researcher provided confidentiality by telling the respondents they could withdraw their responses at any stage of the study, and their information would be anonymous. Thus, each respondent was given some code as student 1 , student 2 , etc. Also, the researcher ensured them the data would be used just for the research purpose and would not be disclosed to any third party.

\subsection{Data Analysis}

First, the obtained data were typed in Microsoft Excel manually by the researcher, and then the file was imported into SPSS 25 data editor. So, the analysis was performed through SPSS 25 program. Means and the standard deviations of each item were calculated to examine the ranking of out-of-class activities. The respondents provided the information on their department, language proficiency level and duration of English study. These data were used to reveal whether there is a relationship between language proficiency and English use outside the classroom.

\section{Findings and Results}

Results of descriptive statistics are provided below.

Table 4. The rating of out-of-class activities

\begin{tabular}{|l|l|l|l|}
\hline Items & Mean & N & Std. Deviation \\
\hline The English language installed on their mobile devices & 4.15 & 87 & 1.483 \\
\hline Surfing the Internet & 3.78 & 87 & 1.224 \\
\hline YouTube videos & 3.66 & 87 & 1.218 \\
\hline Watching movies & 3.63 & 87 & 1.192 \\
\hline Learning lyrics & 3.33 & 87 & 1.444 \\
\hline Text-messaging their teacher & 3.32 & 87 & 1.377 \\
\hline Travelling abroad & 3.30 & 87 & 1.479 \\
\hline Speaking English & 3.21 & 87 & 0.865 \\
\hline Writing e-mails & 3.13 & 87 & 1.388 \\
\hline
\end{tabular}




\begin{tabular}{|l|l|l|l|}
\hline Reading books & 3.11 & 87 & 1.166 \\
\hline Listening to music & 3.03 & 87 & 1.376 \\
\hline Text-messaging their friends & 2.94 & 87 & 1.135 \\
\hline Watching English TV channels & 2.84 & 87 & 1.413 \\
\hline Playing games & 2.78 & 87 & 1.588 \\
\hline Posting Comments on social media & 2.67 & 87 & 1.254 \\
\hline Keeping Diaries & 2.61 & 87 & 1.242 \\
\hline Travelling Inside the country & 2.38 & 87 & 1.260 \\
\hline Listen to the radio & 2.09 & 87 & 1.245 \\
\hline Making phone calls & 2.02 & 87 & 1.110 \\
\hline
\end{tabular}

Table 4 reveals to what extent the freshmen practice English out of the classroom. According to the results, the majority of the students $(m=4.15)$ set their mobile devices in English rather than in their native language. Furthermore, they spend time surfing on the Internet $(m=3.78)$, watching YouTube videos $(m=3.66)$ or movies $(3.63)$ and learning song lyrics the songs $(3.33)$, consecutively.

On the other hand, making phone calls in English $(m=2.02)$, listening to radio broadcasting in English $(m=2.09)$, practicing English while travelling inside their country $(m=2.38)$, keeping a diary $(m=2.61)$, or posting comments in social media in English $(m=2.67)$ are the least practiced activities involving the use of English among EFL undergraduate freshmen.

As almost all standard deviations (SDs) are higher than 1, it is possible to say that the opinions of the students concerning the out-of-class activities applied are not homogenous (Othman, Yin, Sulaiman, Ibrahim, \& Rashid, 2011, p.11).

Table 5 presents the level of students' language proficiency (self-assessed).

Table 5. The level of students' language proficiency according to the departments

\begin{tabular}{llll}
\hline Level & Mean & $\mathrm{N}$ & Std. Deviation \\
Department & 2.11 & 19 & 0.658 \\
\hline English & 2.33 & 18 & 0.767 \\
Physics & 1.84 & 25 & 0.554 \\
Mathematics & 1.68 & 25 & 0.476 \\
Biology & 1.95 & 87 & 0.645 \\
Total & & & \\
\hline
\end{tabular}

According to table 5, while physics education department students' language proficiency level is the highest $(\mathrm{m}=2.33)$, biology has the lowest mean $(m=1.68)$. The departmental results also show that the students' language practice preferences in authentic settings within each department could be viewed as relatively homogenous, since SDs are lower than 1.

Table 6. The extent of out-of-class activity application according to the departments

\begin{tabular}{|c|c|c|c|c|c|c|c|c|c|c|c|c|c|c|c|}
\hline \multirow{3}{*}{ Departments } & \multicolumn{3}{|c|}{ ELT } & \multicolumn{3}{|c|}{ Physics } & \multicolumn{3}{|c|}{ Mathematics } & \multicolumn{3}{|c|}{ Biology } & \multicolumn{3}{|c|}{ Total } \\
\hline & Mean & $\mathrm{N}$ & $\begin{array}{l}\text { Std. } \\
\text { Deviation }\end{array}$ & Mean & $\mathrm{N}$ & $\begin{array}{l}\text { Std. } \\
\text { Deviation }\end{array}$ & Mean & $\mathrm{N}$ & $\begin{array}{l}\text { Std. } \\
\text { Deviatio }\end{array}$ & Mean & $\mathrm{N}$ & $\begin{array}{l}\text { Std. } \\
\text { Deviatic }\end{array}$ & Mean & $\mathrm{N}$ & $\begin{array}{l}\text { Std. } \\
\text { Deviation }\end{array}$ \\
\hline & 3.06 & 19 & 1.320 & 3.29 & 18 & 1.188 & 2.85 & 25 & 1.261 & 3.08 & 25 & 1.218 & 3.05 & 87 & 1.287 \\
\hline
\end{tabular}


When the results in tables 5 and 6 compared, it is possible to state that the students of physics education department have the highest language proficiency mean $(m=2.33)$ and they also use out-of-class activities more than the students from other departments $(m=3.29)$. The level of out-of-class language practice is almost the same at the ELT and biology department $(m=3.06$ and $m=3.08$, respectively); however, their levels of language proficiency is different, higher with ELT students $(m=2.11)$ and lower with biology students $(m=1.68)$. Both the level of language proficiency $(m=2.85)$ and the extent of out-of-class activity $(m=1.84)$ application is the lowest for biology department students. SDs of all departments (concerning the extent of out-of-class activity application) are higher than 1, which reveals that the values were distributed to a large range.

Table 7 presents the data on student language level and the degree of their engagement in out-of-class activities (not regarding the faculty they study at).

Table 7. The extent of out-of-class activities according to language proficiency level

\begin{tabular}{|c|c|c|c|c|c|c|c|c|c|c|c|c|}
\hline \multirow{3}{*}{ Level } & \multicolumn{3}{|c|}{ A1 } & \multicolumn{3}{|c|}{ A2 } & \multicolumn{3}{|c|}{ B1 } & \multicolumn{3}{|c|}{ Total } \\
\hline & Mean & $\mathrm{N}$ & $\begin{array}{l}\text { Std. } \\
\text { Deviation }\end{array}$ & Mean & $\mathrm{N}$ & $\begin{array}{l}\text { Std. } \\
\text { Deviation }\end{array}$ & Mean & $\mathrm{N}$ & $\begin{array}{l}\text { Std. } \\
\text { Deviation }\end{array}$ & Mean & $\mathrm{N}$ & $\begin{array}{l}\text { Std. } \\
\text { Deviation }\end{array}$ \\
\hline & 2.80 & 20 & 1.226 & 3. 08 & 51 & 1.307 & 3.28 & 16 & 1.218 & 3.05 & 87 & 1.287 \\
\hline
\end{tabular}

According to these results, the students in this research had three proficiency levels: $A 1, A 2$, and $B 1$. It can be seen that the learners whose language level was B1 (the highest level) engage in out-of-class activities more $(m=3.28)$ than the others, while the lowest level of students' English proficiency (A1) is related to the lowest level of out-of-class activity engagement $(m=2.80)$. The SDs on all three English proficiency levels are more than 1, which reveals that their levels are rather heterogeneous.

Table 8 provides data concerning the duration of students' previous experience of English study.

Table 8. The extent of out-of-class activities according to the duration of previous English study

\begin{tabular}{|c|c|c|c|c|c|c|c|c|c|c|c|c|}
\hline \multirow{3}{*}{$\begin{array}{l}\text { English- } \\
\text { Study- Year }\end{array}$} & \multicolumn{4}{|c|}{$0-3$ years } & \multicolumn{2}{|c|}{$4-6$ years } & \multicolumn{4}{|c|}{7 and more years } & \multicolumn{2}{|c|}{ Total } \\
\hline & Mean & $\mathrm{N}$ & $\begin{array}{l}\text { Std. } \\
\text { Deviation }\end{array}$ & Mean & $\mathrm{N}$ & $\begin{array}{l}\text { Std. } \\
\text { Deviation }\end{array}$ & Mean & N & $\begin{array}{l}\text { Std. } \\
\text { Deviation }\end{array}$ & Mean & $\mathrm{N}$ & $\begin{array}{l}\text { Std. } \\
\text { Deviation }\end{array}$ \\
\hline & 3.05 & 21 & 1.308 & 3.07 & 8 & 1.080 & 3.05 & 58 & 1.296 & 3.05 & 87 & 1.287 \\
\hline
\end{tabular}

Most of the participants (66\%) had an English language study background of more than seven years, but the various years of English study did not change the result of the extent of out-of-class language engagement significantly among the groups. All results are between $m=3.05$ and $m=3.07$.

\section{Discussion}

Lai and Gu (2011) advocate that technological tools and settings take a significant part in learning outside the classrooms; so, television, movies and radio have been among the out-of-class activities selections of the EFL students as stated in the previous studies. Similar findings have been obtained for the language learners in this study.

In some other researches (Chusanachoti, 2009, Grau, 2009, Maros \& Saad, 2016, Sargsyan \& Kurghinyan, 2016, Sundqvist, 2009), the scholars obtained more or less similar results, that is, students of various ages in their free time engage in technology-based receptive language activities like watching movies or videos, surfing on the Internet, social media, etc. which are considered as a 
kind of entertaining activities. In the given study, most of the language learners also prefer to engage in receptive activities (watching movies, videos, surfing on the Internet, etc.). They tend to use more often their first language for activities requiring productive skills - communicating with others while travelling in their country, keeping diary, posting comments, or making phone calls. They might employ L1 to express their ideas or feelings more comfortably and properly since they might not feel the foreign language requirement for those interactions. On the other hand, they practice English more when they feel a practical need in it - while texting messages to their English teachers, travelling abroad, speaking with foreigners, writing emails (mostly undergraduate students use email to communicate with their teachers for their home tasks), or reading books.

\section{Limitations of the Study}

The data were obtained from just one private university's EFL freshmen of the faculty of education, so the results cannot be generalized for all EFL undergraduate students, especially public university students. Another limitation of the study is the application of only a questionnaire as a measurement tool dueto time limitation. Semi-structured interviews could be designed to obtain deeper and more reliable results.

\section{Conclusion}

Hyland (2004) claims that the learners' willpower to involve in language activities out of the classroom promotes language learners' proficiency. Similarly, the results in this study illustrate that proficient language users apply more out-of-class L2 activities compared to students with lower level of $L 2$ proficiency (at A1 level, $m=2.80$, at A2 level $m=3$. 08 , and at B1 level, $m=3.28$, respectively). As the language proficiency level increases, the language practice outside the classroom also grows.

Answering the first research question, it was found out in the research that the participants in the study first-year EFL students apply out-of-class activities beneficial for language learning at moderate level with $m=3.05$, which can be viewed as acceptable extent of their application. However, it is still not at desirable level. What is more, the EFL freshmen prefer to use English through mostly entertaining activities such as watching movies, videos, or surfing the Internet; this could be related to the characteristics of the young adults.

According to the findings in this study, it could be also stated that the EFL undergraduate first-year students' language engagement in authentic settings enhances their linguistic competence. Some other studies obtained similar results. In Briggs' study (2015), for instance, the amount time spentspeaking with foreign language natives was proved to positively relate to the level of students' foreign accent and vocabulary gain. Other researches showed evidence for the positive association betweenout-ofclass activities and language oral proficiency (Hernandez, 2010; Segalowitz \& Freed, 2004 as cited in Brigg, 2015), lexical knowledge (Segalowitz \& Freed, 2004 as cited in Brigg, 2015), phonological control (Munoz \& Llanes, 2014 as cited in Brigg, 2015), intercultural competence (Martinsen, 2011). What is more, the findings show that the students in this research do not keep any written record in L2 like keeping diary and seldom use L2 out-of class productively. 


\section{Recommendations}

Although the application of out-of-class language activities seems positively related to EFL students' language proficiency, some EFL learners are self-motivated and capable of managing out-of-class activities effectively, while others may need teachers' assistance to create practice settings in 'real world' in the process of language learning. Therefore, language teachers can investigate the students' practice environment outside the school to identify which students need help to be motivated to use L2 beyond the classroom. Especially, teachers can encourage their students in their office hours to engage in out-of-class language activities by themselves. Teachers should teach them how to engage in both individual activities such as watching movies, listening to music, or reading books and group activities such as brainstorming about daily concerns (family, friends, interests, etc.), books, movies, games and so on. For further studies on the topic, factors affecting the students' out-of-class practice (socioeconomic status, parents', friends' or teacher impact) can be investigated.

\section{Acknowledgement}

I would like to express my gratitude to Prof. Natela Doghonadze, Educational Sciences Doctoral Program Coordinator at International Black Sea University, for her valuable supervision, guidance, and support in that study. 


\section{References}

Bala, E. \& Bala. A. (2018). Learning to learn: Strategopedia. International Journal of Social Sciences \& Educational Studies, 5 (2), 164170.

Bialystok, E. (1981). The role of conscious strategies in second language proficiency. The Modern Language Journal, 65 (1), $24-35$.

Benson, P. (2013). Teaching and Researching: Autonomy in Language Learning. New York: Routledge.

Benson, P. \& Reinders, H. (Eds.). (2011). Beyond the Language Classroom. UK: Palgrave Macmillan.

Briggs, J.G. (2015). Out-of-class language contact and vocabulary gain in a study abroad context. System, 53, $129-140$.

Chan, H.W. (2016). Popular culture, English out-of-class activities, and learner autonomy among highly proficient secondary students in Hong Kong. Universal Journal of Educational Research, 4 (8), 1918-1923.

Chusanachoti, R. (2009). EFL Learning Through Language Activities Outside the Classroom: A Case Study of English Education Students in Thailand. Doctoral dissertation. East Lansing, Ml: Michigan State University.

Coşkun, A. (2016). Benefits of out-of-class speaking activities for EFL students. Uluslararası Türkçe Edebiyat Kültür Eğitim (TEKE) Dergisi, 5(3), 1448-1464.

De Wilde, V., Brysbaert, M., \& Eyckmans, J. (2020). Learning English through out-of-school exposure. Which levels of language proficiency are attained and which types of input are important? Bilingualism: Language and Cognition, 23 (1), $171-185$.

Ferdous, T. (2013). Use of English Beyond the Classroom Wall: A Study of Undergraduate Students' Out-of-class English Learning Activities. Doctoral dissertation. Dhaka, Bangladesh: BRAC University).

Grau, M. (2009). Worlds apart? English in German youth cultures and in educational settings. World Englishes, 28 (2), $160-174$.

Hyland, F. (2004). Learning autonomously: Contextualising out-of-class English language learning. Language awareness, 13 (3), 180-202.

Hsieh, H.C. \& Hsieh, H.L. (2019). Undergraduates' out-of-class learning: Exploring EFL students' autonomous learning behaviors and their usage of resources. Education Sciences, 9 (3), 159. DOI: 10.3390/educsci9030159

Lai, C. \& Gu, M. (2011). Self-regulated out-of-class language learning with technology. Computer Assisted Language Learning, 24 (4), 317-335.

Lai, C., Zhu, W., \& Gong, G. (2015). Understanding the quality of out-of-class English learning. TESOL quarterly, 49 (2), $278-308$.

Lancaster, N.K. (2018). Extramural exposure and language attainment: The examination of input-related variables in CLIL

programmes. Retrieved from https://digibug.ugr.es/bitstream/handle/10481/54024/5_NINA\%20KAREN\%20LANCASTER.p $\mathrm{df}$ ? sequence $=1$ \&isAllowed $=\mathrm{y}$

Long, M.H. \& Richards, J. C. (1990). The Development of Second Language Proficiency. Cambridge: Cambridge University Press.

Maros, M. \& Saad, N.S.M. (2016). The out-of-class language learning strategies of international students in Malaysia. International Journal of Asian Social Science, 6 (8), 478-486.

Nunan, D. (2012). Learner-Centered English Language Education: The Selected Works of David Nunan. New York: Routledge. 
Nunan, D. \& Richards, J.C. (2015). Language Learning beyond the Classroom. New York and Oxford: Routledge.

Olsson, E. (2016). On the Impact of Extramural English and CLIL on Productive Vocabulary. Doctoral dissertation. Göteborg, Sweden: Göteborg University.

Othman, A.R., Yin, T.S., Sulaiman, S., Ibrahim, M.I.M., \& Rashid, M.R. (2011). Application of mean and standard deviation in questionnaire surveys. Discovering Mathematics (Menemui Matematik), 33 (1), 11-22.

Pirainen-Marsh, A. \& Tainio, L. (2009). Other-repetition as a resource for participation in the activity of playing a video game. The Modern Language Journal, 93(2), 153-169.

Ranta, E. (2010). English in the real world vs. English at school: Finnish English teachers' and students' views. International Journal of Applied Linguistics, 20 (2), 156-177.

Richards, J.C. (2015). The changing face of language learning: Learning beyond the classroom. RELC Journal, 46 (1), 5-22.

Sargsyan, M. \& Kurghinyan, A. (2016). The use of English language outside the classroom. Journal of Language and Cultural Education, 4 (1), 29-47.

Shvidko, E., Evans, N.W., \& Hartshorn, K. J. (2015). Factors affecting language use outside the ESL classroom: Student perspectives. System, 51, 11-27.

Spratt, M., Humphreys, G., \& Chan, V. (2002). Autonomy and motivation: which comes first?

Language Teaching Research, 6, 245-266.

Sundqvist, P. (2009). Extramural English Matters: Out-of-school English and Its Impact on Swedish Ninth Graders' Oral Proficiency and Vocabulary. Doctoral dissertation. Karlstad, Sweden: Karlstad University.

Sundqvist, P. \& Sylvén, L.K. (2016). Extramural English in Teaching and Learning. London, UK: Palgrave Macmillan.

Sylvén, L.K. (2006). How is extramural exposure to English among Swedish school students used in the CLIL classroom. Current Research on CLIL, 15(3), 47-53.

Tavakoli, N., Shakeri, N., \& Granbarzadeh, T. (2016). Language learning beyond the classroom. JIEB, 4, 153-161.

Victori, M., \& Lockhart, W. (1995). Enhancing metacognition in self-directed language learning. System, 23 (2), 223-234.

Waite, S. (2011). Teaching and learning outside the classroom: personal values, alternative pedagogies and standards. Education $3-13,39(1), 65-82$.

Wenden, A. L. (2001). Metacognitive knowledge in SLA: The neglected variable. In M. P. Breen (Ed.). Learner Contributions to Language Learning: New Directions in Research, 44-64. NY: Routledge.

Williams, C. (2007). Research methods. Journal of Business \& Economics Research (JBER), 5, (3), 65-71. 


\section{Appendix: Questionnaire}

\section{English Learning Outside of the Classroom}

Dear Students,

This questionnaire is a part of a research paper, and the purpose is to analyze your relevancy degree of English usage outside the classroom. The obtained data will be used just for research purpose and will be anonymous. You do not need to mention your names. Thank you for your response.

\section{SECTION I}

Please choose the appropriate option or complete the blanks.

1. Gender:

a. Female

b. Male

2. Age

3. At which level classroom are you studying in this term? (Levels A1, A2, B1, B2, C1, C2)

4. How long did you study English before you started the university?
a. $0-3$
b. 4-6
c. 7-more

5. What is your department?

a. ELT

b. Physics

c. Mathematics

d. Biology

6. Indicate your native language

a. Kurdish

b. Arabic

Other 


\section{SECTION I}

\begin{tabular}{|c|c|c|c|c|c|c|}
\hline No & Outside of the classroom, & $\begin{array}{c}\text { Never } \\
\text { (1) }\end{array}$ & $\begin{array}{c}\text { Seldom } \\
\text { (2) }\end{array}$ & $\begin{array}{c}\text { Sometimes } \\
\text { (3) }\end{array}$ & $\begin{array}{l}\text { Often } \\
\text { (4) }\end{array}$ & $\begin{array}{c}\text { Almost } \\
\text { Always } \\
\text { (5) }\end{array}$ \\
\hline 7 & $\begin{array}{l}\text { I speak English with foreigners, international } \\
\text { students, teachers, and friends. }\end{array}$ & & & & & \\
\hline 8 & I read books in English for fun. & & & & & \\
\hline 9 & I listen to music in English. & & & & & \\
\hline 10 & I try to learn the lyrics of English songs. & & & & & \\
\hline 11 & I watch movie in English. & & & & & \\
\hline 12 & I watch YouTube videos in English. & & & & & \\
\hline 13 & I watch English channels on TV. & & & & & \\
\hline 14 & I adjust my mobile devices' language in English. & & & & & \\
\hline 15 & I use English during travelling inside the country. & & & & & \\
\hline 16 & I use English during travelling abroad. & & & & & \\
\hline 17 & I surf on the Internet in English. & & & & & \\
\hline 18 & I listen to radio in English. & & & & & \\
\hline 19 & I play games in English. & & & & & \\
\hline 20 & I send my text messages in English to my friends. & & & & & \\
\hline 21 & I send my text messages in English to my teachers. & & & & & \\
\hline 22 & I write emails in English. & & & & & \\
\hline 23 & I keep a diary in English. & & & & & \\
\hline 24 & $\begin{array}{l}\text { I post comments on social media such as Facebook, } \\
\text { Instagram in English. }\end{array}$ & & & & & \\
\hline 25 & I make my phone call in English. & & & & & \\
\hline
\end{tabular}

